\title{
Hegel and Chinese Marxism
}

\author{
Tom ROCKMORE*
}

\begin{abstract}
China is presently embarking on the huge task of realizing what President Xi Jinping recently called the Chinese Dream. China is officially Marxist, and Marx thus inspires this dream in his assigned status as the "official guide" to the ongoing Chinese Revolution. This paper will focus on the crucial relation between Hegel and Chinese Marxism. Marx is a key Hegelian, critical of, but strongly dependent on, Hegel. Since the Chinese Dream is not Hegelian, but rather anti-Hegelian, it is unlikely, as I will be arguing, to be realized in a recognizably Marxian form.
\end{abstract}

Keywords: Hegel, China, Marxism, Marx, Engels

\section{Hegel in kitajski marksizem}

\section{Izvleček}

Kitajska se podaja na pot uresničitve projekta, ki ga je predsednik Xi Jinping pred kratkim imenoval »kitajske sanje«. Kitajska je uradno marksistična in Marx zaradi statusa »uradnega vodiča« sedanje kitajske revolucije, ki so mu ga pripisali, navdihuje te sanje. Članek se bo osredotočil na ključno razmerje med Heglom in kitajskim marksizmom. Marx je ključni hegelianec, ki do Hegla ni le kritičen, ampak je tudi odvisen od njega. »Kitajske sanje« pa niso hegelianske, temveč prej antihegelianske, zato je, kot bo razloženo, malo verjetno, da se bodo uresničile $\mathrm{v}$ prepoznavno marksistični obliki.

Ključne besede: Hegel, Kitajska, Marxism, Marx, Engels

Tom ROCKMORE, Department of Philosophy, Peking University,

China.

Email address: rockmore[at]duq.edu

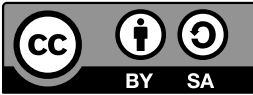




\section{On the Relation of Marx and Hegel}

Marx's followers as well as his critics tend to approach him through Marxism. Classical Marxism, often called simply Marxism, is the theory invented by Engels and further developed by his followers. Engels, who has positivist tendencies, substitutes science for philosophy in his reading of Marx. His study of Feuerbach presents an influential view later restated by him and others.

Engels often suggests, incorrectly in my view, that Marx is responsible for the extra-philosophical, scientific component of Marxism. One of the more important passages occurs in his speech at Marx's graveside. In the eulogy, Engels generously compares Marx to Darwin. He claims that Marx "discovered the law of development of human history," which, if this is a reference to political economy, presumably means that economics is prior to every other explanatory factor, specifically in its capacity as "the special law of motion governing the present-day capitalist mode of production and bourgeois society that this mode of production has created." (Engels 1989, 468) Other observers reject this interpretation of Marx. According to Ernest Mandel, a Trotskyist theoretician, "He [i. e. Marx] was not seeking universal laws of economic organization. Indeed, one of the essential theses of Capital is that no such laws exist." (Mandel 1982,11) Similarly, in his recent biography of Marx, G. S. Jones calls attention to the difference between Engels' favourable comparison of Marx's view, which he describes as the establishment of the law of historical development, and Darwin's theory of natural selection that, Jones points out, is not and should not be interpreted as deterministic. (see Stedman Jones 2016, 566)

Despite its limits, Engels' anti-Hegelian interpretation of Marx quickly became canonical. His anti-Hegelian approach to Marx has long influenced Russian Marxism and continues to influence Chinese Marxism. In broad terms Chinese Marxism is dependent on two main sources: Russian Marxism and the Chinese intellectual tradition. The shared Russian and Chinese anti-Hegelian interpretation of Marx was called into question in the middle of the last century through the relatively late publication of crucial Marxian texts, that is texts prepared by Marx and that are crucial for understanding his position.

Russian Marxism is strongly influenced by Lenin, who was active early in the twentieth century. When he was active, a number of important writings, crucial for understanding Marx's position, were still unpublished. They include the Paris Manuscripts, the Grundrisse, the manuscripts routinely known as Theories of Surplus Value, the German Ideology, and so on.

Lenin's political credentials exceed either his philosophical training or his philosophical competence. Lenin was interested in and, unlike Engels, partly trained 
in philosophy. But he was understandably more concerned with bringing about a successful revolution than in winning a philosophical debate. His understanding of both Marx and Marxism is almost wholly based on Engels rather than on Marx. In his most important philosophical foray, Materialism and Empiriocriticism, he cites Engels more than three hundred times but Marx only once.

Lenin's interest in Hegel was stimulated by his teacher, Plekhanov, a Hegelian Marxist. Lenin was initially concerned with Hegel at the very end of the nineteenth century. He later returned to Hegel after he wrote Materialism and Empiriocriticism (1909), particularly several years later when he was writing his "Philosophical Notebooks" (1914). This unfinished text reflects his effort to master Aristotle, Feuerbach, Marx and Deborin, but above all Hegel. ${ }^{1}$

Due to his early death, Lenin did not live to develop his understanding of Hegel. Stalin, Lenin's political heir, later codified the Marxist account of Marx. In "Dialectical and Historical Materialism" he notes, in silently conflating Marx and Engels and in paraphrasing the former's remarks on dialectic in the Afterword to the second edition of Capital vol. 1, that Marx and Engels took from the Hegelian dialectics only its "rational kernel" while casting aside its idealistic shell. According to Stalin, Marx provided dialectic with a modern scientific form. Though there were Hegelian Marxists such as Ewald Ilyenkov in the Soviet Union, in part because of the enduring influence of Engels, Russian Marxism has always been basically anti-Hegelian, and if Marx is a Hegelian, anti-Marxian.

\section{On the Soviet Background of Chinese Marxism}

Individual Chinese thinkers, perhaps foremost among them Zhang Shiying (see Wang 2014, 90-96), are centrally interested in Hegel. Yet Chinese Marxism mainly follows the anti-Hegelian lead of Engels, traditional Marxism, and Russian Marxism for two reasons. On the one hand, there is the political pressure to maintain the Marxist vision of Marx. On the other, there is the fact that Chinese Marxism, like Russian Marxism, arose before the publication in the middle of the last century of crucial Marxian texts pointing to Hegel's central role in the formulation of Marx's position.

The discovery of Hegelian Marxism by Lukàcs and Korsch in the early 1920s had a powerful and enduring impact. With exceptions, it is at least plausible that Western Marxism as a whole can be described as broadly Hegelian. (see Anderson 1976) In the absence of statistics, it is difficult to be precise about the importance

1 See, for a sympathetic reading of Lenin's efforts to master Hegel, Anderson 1995. 
of Hegel in the Chinese Marxist debate. The Hegel debate in China, though perhaps large - though how large is unclear-if for no other reason than the large number of Chinese Marxists, is comparatively small. In any case it is not large in comparison to the discussion of Chinese Marxism. The debate on Chinese Marxism is omnipresent, though mainly on the ideological level. Anyone who has spent time in China is aware that ideological, forced-feeding of the Chinese version of Marxism is obligatory fare for all Chinese students. To the best of my knowledge no Chinese university lacks a Marxist school. These, however, routinely dispense a form of Marxist propaganda that differs in kind from philosophical Marxism that is studied in some but not all departments of philosophy.

It is important to distinguish between those who inculcate Marx and Marxism as a form of propaganda and those who study it seriously, as one would study other forms of philosophy. The subjective impression of the present writer is that Chinese students of Marx and Marxism are often less aware of Marxism outside China than their Western counterparts. For obvious reasons, given such factors as the important language barrier, Hegel's criticism of Chinese philosophy, and the strong official Chinese identification with Marxist ideology, Chinese Marxist students often have a relatively weak grasp of Western Marxism. Other reasons include the fact that Chinese scholars tend not to know German, or at least not to know it well, not to be more than distantly aware of the Western Hegelian Marxist discussion, nor to be more than vaguely familiar with recent Western Marxist publications, and so on. Though there are exceptions, above all Li Zehou, in comparison to Western Marxists the Chinese show relatively less interest in or awareness of Hegelian Marxism.

Li's anthropological ontology, the basis of his approach to modernity, underlies his effort to transform Kant's dualistic theory of subjectivity into a monistic, materialist theory of subjectivity. His theory is both original and atypical of the Chinese Marxist debate. ${ }^{2}$ It is thus not surprising if a recent study of Chinese Marxism has nothing specific to say about the role of Hegel in Chinese Marxism. (see Chan 2003)

Chinese Marxism arose in stages, initially through translations from German, Russian and Japanese sources early in the twentieth century. It later developed through the importation into China of the influential Russian debate between the mechanists and the dialecticians (or so-called Deborinists) concerning Marxist materialism. This debate, which is sometimes cast as the first great debate of Soviet philosophy, interested Nikolai Bukharin, a tragic political figure later liquidated by Stalin, and as well as Stalin himself, who favoured the mechanists.

2 See, for an exception, Gu 1996, 205-45. 
Russian mechanists were mainly concerned with science or the philosophy of science. They tended like Engels to favour natural science. Lyubov Akselrod, the leading mechanist, was better known under the pseudonym Ortodoks. She studied in Berne and later became a Marxist. In the debate on empiriocriticism she criticized both Lenin and Bogdanov. As a Marxist she was allied with Plekhanov. Russian dialecticians, unlike the mechanists, were interested in Hegel, and, as the term suggests, took a dialectical approach fostered by Abram Deborin, a Soviet Marxist philosopher, and his allies. Deborin was a member of the Academy of Sciences and a former Menshevik. Kolakowski captures the main theme here in a single sentence:

The opposition between the mechanists and the dialecticians represented the opposition of the natural sciences to philosophical interference, while the dialecticians stood for the supremacy of philosophy over the sciences and thus reflected the characteristic tendency of Soviet ideological development (Kolakowski 1978, 64).

In 1929 at a meeting of the Second All-Union Conference of Marxist-Leninist Scientific Institutions a resolution was passed condemning mechanism. In normal circumstances, this would have meant an end to the debate. Yet one year later the controversy broke out anew over the suspicion of "menshivizing idealism," or rendering idealism politically acceptable. This term, which was in wide use from approximately 1930 until 1950, referred to the supposed separation of theory and practice as well as other egregious errors allegedly committed by the Deborinists. The so-called new view, which was advanced by M. B. Mitin and P.F. Yudin, adopted dialectical materialism as well as the so-called dialectics of nature favoured by Engels and the mechanists, and later Stalin. This view, which was represented by Mitin and Yudin, was later codified in Stalin's view of dialectical materialism in his "History of the CPSU (Short Course, 1938)." (see Stalin 1941) Philosophy at the time was not for the faint of heart. Deborin, the central figure for the dialecticians, and Akselrod, the central figure for the mechanists, both survived, but many other participants in the debate simply disappeared.

\section{Chinese Marxism Reacts against Soviet Marxism}

The Soviet debate between the mechanists and the dialecticians that was influential in the Russian Marxist debate was also influential in the development of Chinese Marxism. With Stalin's support, Mitin quickly rose through the ranks. In the 1930s Chinese dialectical materialism was formalized under his influence 
on the Chinese debate. Li Da and Ai Siqi translated many of Mitin's writings into Chinese. The Chinese Marxists strongly supported Mitin against Deborin. (see Knight 2005) Then as now, the Chinese were understandably uninterested in following foreign models.

This disinterest in simply taking over a foreign model not surprisingly led to an interest in working out a form of Marxism applicable to the specific Chinese situation. Mao Zedong, for instance, was later critical of Mitin's so-called new philosophy, hence of Stalin's conception of dialectical materialism. In the late 1930s, Mao, under Engels' influence, began to develop a Chinese version of dialectical materialism in emphasizing the concepts of contradiction and practice. For mainly political reasons, Mao's view continued to be influential until at least the 1970s. Yet trained Western philosophers are often sceptical of Mao's philosophical understanding and intellectual accomplishments. Leszek Kolakowski, for instance, who knew Marxism very well, described Mao's so-called peasant Marxism as "a series of repetitions of a few commonplaces of Leninist Stalinist Marxism." (see Kolakowski 1978, 3: 499)

The term "Mao sixiang," or Mao's thought, which is described as "Marxism-Leninism applied in a Chinese context," was officially adopted in the Chinese Constitution. Yet after Deng Xiaoping said it was not always necessary to follow Mao, his position was often disregarded. For instance, on a recent anniversary of the Cultural Revolution the Chinese government said that this series of events was a mistake that would not be repeated.

Still, Mao's view continued to be influential at least into the 1970s, mainly for political reasons. Mao was especially interested in practice and contradiction (maodun). In "On Practice" he argues that knowledge comes from practice, and that true knowledge is verified by practice and other approaches fail to grasp the importance of dialectical materialism. According to Mao, the truth-value of ideas can only be judged in practice. In "On Contradiction" he breaks with Marx in following Engels' view that contradiction is present in matter itself as well as in ideas in the brain. According to Mao, there is always a struggle between different contradictory aspects as well as what he called a principal contradiction. The class struggle, which is the main contradiction, can only be resolved through a revolution that overcomes the antagonism between labour and capital.

Chinese Marxism in the post-Mao period is, like the great Confucian classics, and like China itself, intensely practical. ${ }^{3}$ Deng Xiaoping is often said to have saved the Chinese economy after the Cultural Revolution, and typically insisted

3 See, for recent helpful discussion, Xu 2016. 
on practice almost to the exclusion of theory. Beginning in 1978, he promoted the slogan shishi-qiushi. This was mentioned in a speech at the Sixth National Congress CCP in reference to pragmatism, and later became a key element of Maoism. Beginning in 1978, this slogan was promoted by Deng as a central component of socialism with Chinese characteristics. In echoing this slogan, Deng famously said it does not matter if a cat is white or black so long as it catches mice. In a widely known article that captures Deng's pragmatic approach, Hu Fuming, an associate professor of philosophy at Nanking University proclaimed: "Practice is the sole criterion for testing truth" (1978) (Hu 1993).

The phrase identified with Deng suggests two points concerning the origin and interpretation of this slogan. On the one hand, there is its origin. As is often the case in China, slogans that come to the attention of the public have a long prior tradition. An example is President Xi Jinping's recent reference in a visit to the National Museum of China (2012) to the "Chinese Dream" (zhongguo meng or zhongguomeng).

Xi's language here is consistent with Chinese political practice. All series of Chinese presidents have coined slogans. Jiang Zemin proposed the slogan "Three Represents" to suggest that the Communist Party of China represents advanced social forces, advanced culture, and the interests of the majority. Hu Jintao suggested the idea of a moderately well-off society in referring to the Confucian term xiao kang she hui. This term describes a society composed of a functional middle class. According to President Xi, the Chinese dream includes the "Four Comprehensives" or si ge quan mian zhan lüe bu ju. This slogan refers to the conception of a moderately prosperous society, including deepening reform, governing according to law, and the strict governance of the party.

This phrase was originally written during the Southern Song dynasty by the poet, Zheng Sixiao's poem, "Flowing Spring." Zheng composed the famous line: "Heart full of [the] China Dream." Similarly, Deng's slogan that was cited earlier by Mao Zedong in 1938 can be traced back as early as the Han Dynasty. The Book of Han, also known as the History of the Former Han, a history of China finished in 111, contains the following passage: "he jian xian wang de yi xiao jing qian er nian li xiu gu shishi-qiushi."

The proper interpretation of this phrase is unclear. "Shishi qiushi" means to seek truth from facts, as in the idiom about a practical and realistic work style, "shishiqiushi de gongzuo zuofeng." Deng's famous insistence on practice over theory could mean different things. In the West the distinction between theory and practice goes all the way back in the philosophical tradition to Aristotle. Late in the 18th century, Kant identifies the difficulty in an article titled "On the common saying: That may be correct in theory, but it is of no use in practice" (1793). 
Marx's initial criticisms of Hegel in the early 1840s already point to the difference between traditional philosophy, which he thinks is satisfied with mere theory that changes nothing other than itself, and a new form of theory that realizes itself in changing practice. At stake, as Marx famously points out, is only interpreting the world, or on the other hand changing it. Following Marx, Marxism routinely stresses the pre-eminence of practice over theory. With that distinction in mind, Deng's slogan might be intended to signal the interest in practice, or to indicate a relative emphasis on practice over theory, or again to point out that practice is the highest value, or even some combination of the above. We cannot answer that question here. But suffice to say that Deng was centrally concerned in the midst of the political and social chaos that occurred in the wake of the Cultural Revolution to focus attention on practice, especially the economy. With that in mind, we can say that in this specific context Deng's emphasis on practice was a strategic move that enabled him to undertake deep revisions to Mao's policies.

The pragmatic, anti-theoretical transformation of Chinese Marxism continues today. As in the Soviet Union during Stalin's time, it is reflected in the use of primers to inculcate a specific governmental view of Marxism-Leninism at all levels of the Chinese educational system. Yet care is taken to avoid any criticism of the government in its task as the self-anointed guardian of the Chinese Marxist view.

An important example lies in the debate on humanism in the West after the publication of the Paris Manuscripts. This text contains an important account of alienation. Alienation and humanism are linked concepts. Alienation points to the failure to develop as an individual in modern industrial society. Humanism focusses on the idea of the realization of human beings as individuals as the goal of a future version of modern industrial society. The discussion of alienation produced a split between Marx and Marxism. It simultaneously called attention to the important philosophical core in Marx's position as well as to the possible link of Marxist institutional practices with forms of alienation.

In the West, in reaction to the relatively late publication of Marx's Paris Manuscripts as well as the Grundrisse, the French Marxist philosopher Althusser rushed to the defence of Marxism. The French thinker's view, which was clearly intended to support the one institutionalized in the French Communist Party, was that the mature Marx was a scientist who, in following Feuerbach away from Hegel as well as idealism and philosophy toward science, had decisively left his early philosophical interests behind.

The theme of Marx's humanism played out in an analogous manner in the East as well. In China, reference to this concept could be taken as criticism of the Chinese government. After 1978, after the Cultural Revolution, after the downfall of the Gang of Four, and after Mao had left the scene, a new intellectual discussion with 
important humanist elements quickly arose. This moved away from a discussion dominated by the needs of the Party and toward debate loosely centred on what can be called traditional humanism. The lead up to the debate on alienation began with discussion of the criterion of truth in 1978, before quickly turning to the concepts of humanism and alienation in linking together the ability to think independently with the concept of a human being. ${ }^{4}$

The theme of alienation was raised in early 1980 by Zhao Yang, deputy director of the PCC propaganda department, and Wang Ruoshui, deputy director of the People's Daily. Around 1983, the theme of "man" (ren) was a central topic in all the Chinese social and human sciences. (see Wang 1983) The Chinese government, which took this debate as threatening, rapidly intervened. Hu Qiaomu, the Party's chief ideological authority, accused its participants of supporting bourgeois humanism. ${ }^{5}$ But Li Keming, president of South China Normal University, further insisted that Marxist philosophy needed to deal with the problem of alienation. ${ }^{6}$

Gao Ertai also played an important role here. ${ }^{7}$ In a long article entitled "Humanism: A Memorandum on the Contemporary Debate," he refuted Hu Qiaomu and supported humanist Marxists accused of being sources of "spiritual pollution." Since Deng had already made known his views in his speech, Gao's publication required considerable courage, like $\mathrm{Xu}$ Changfu's writings today. Gao later published his views on alienation in an article entitled "On the Concept of Alienation."

All in all, in view of its importance, the Chinese Marxist debate on alienation, which lasted from 1980 to 1984, was very short, in no small measure because the political authorities took steps to end it as quickly as possible. It is then not an accident that, in his speech on October 3, 1983 entitled "The Party's urgent tasks on the organizational and ideological fronts," Deng said that alienation could not occur in a socialist country, and need not be discussed since that would only confuse the people. ${ }^{10}$

$4 \quad$ For remarks on humanism and alienation, I rely on Yuhuai He 2001.

5 See Hu Qiaomu, "On problems concerning humanism and alienation," "Guanyu rendao zhuyi yihua wenti," in Renmin Ribao 27 January 1984).

6 "A Marxist Philosophy Should Deal with the Alienation Theory ("Makesi zhuyi zhexue yao yanjiu yibua lilun"), in Guangzhou Ribao 8 December 1986.

7 For remarks on the discussion surrounding alienation in China, see Lin, Rosemont, and Ames 1995, 727-58.

8 "rendaozhuyi-dangdai zhenglun de beiwanglu" in Sichuan shida xuebao, 4, 1986.

9 “lun yihua gainian” 1989.

10 Speech at the Second Plenary Session of the Twelfth Central Committee of the Communist Party of China, in Selected Works of Deng Xiaoping, vol. 3, 1982-1992. 
Marxism in China currently bears little resemblance to Marxism as it is discussed and practiced in Western universities. Chinese Marxism is routinely referred to through the term "zhuyi," meaning "ideology," more precisely the political ideology of the Chinese government in which it plays an important role. The history of Marxism has often been the theatre of intense theoretical struggles among powerful intellectuals. In contrast, this intellectual dimension was much reduced in the Soviet Union, where it was simply not possible to disagree with Stalin's view of Marxism. Chinese Marxism today mainly faithfully reflects the political views of the Chinese government.

\section{Hegelian and non-Hegelian Marxism}

Marx's position begins in a dialogue with Hegel that in different ways runs throughout his entire corpus. The proper interpretation of this dialogue remains controversial. After extensive discussion, it is fair to say that while much has been attempted little, not nearly enough, has been learned. The difference between Hegelian and non-Hegelian Marxism is crucial. Marx's reaction to and appropriation of Hegelian and other German idealist insights, and his criticism of Hegelian and German idealism, is not well understood. His relation to classical German philosophy is also unclear. Marx's position is based on the idea of the revolutionary subject, largely borrowed from Fichte, as self-developing in and through its interaction with others and with the surrounding natural world. But, as noted above, non-Hegelian Marxism is based on revolutionary self-development through knowledge of what Engels thinks is the law of human history.

The belated publication of a number of Marxian writings in mid-twentieth century, above all the Paris Manuscripts and the Grundrisse, seems to many observers to tip the balance toward a Hegelian approach to Marx incompatible with other, non-Hegelian interpretations. Both texts suggest continuity, including a continuous interaction with and reliance on Hegel, and in my own view to a lesser but crucial extent Fichte as well, rather than discontinuity in Marx's development.

Engels, who has always been central to the reception of Marx's theories, was selftaught in philosophy. He was neither competent to evaluate nor perhaps even to understand either Hegel's theories or Marx's reception of them. His lack of an adequate philosophical background is apparent in his literally fantastic suggestion that Kant's thing in itself is overcome by practice and industry. (see Engels 1996, 23) Classical Marxism, which is often simply identified as Marxism, is mainly due to Engels. Engels in turn relies on the supposedly crucial role of Feuerbach in Marx's intellectual trajectory. According to Engels, Marx followed Feuerbach 
away from Hegel, away from classical German philosophy, away from philosophy, and towards materialism and science. In sum, and according to Engels, Marx overcame his early false start in simply throwing aside Hegel and in opting instead for the intellectual tools available in modern science.

This is not the place to provide an account of Marx's relation to Hegel, even in outline. Suffice it to say that Hegel, who was the most important living German thinker when he died, only passed from the scene in 1831. Marx received a Ph.D. in philosophy in 1841, when, though his influence was declining, Hegel was still the central philosophical figure. As his widely known letter to his father indicates, Marx became deeply interested in Hegel while still an adolescent, and this interest later continued throughout his career.

Hegel's views are inseparable from his continual interpretation of and reaction to Kant. Althusser notwithstanding, Marx's lifelong dialogue with Hegel similarly takes different forms at different times. It includes: Hegelian treatment of ancient Greek materialism in the Dissertation, a Hegelian conception of the proletariat based on the master and slave passage in the Phenomenology of Spirit as the motor of a future revolution, criticism of Hegel in the Paris Manuscripts as well as the formulation of Hegelian conceptions of objectification and alienation, a theory of surplus value based on the conception of self-objectification in a series of more economic writings, the restatement of the conception of alienation as fetishism in Capital, and so on.

Marxism, which, like ice cream, comes in different flavours, advances different views of Hegel. With some exceptions, Western Marxism is Hegelian (see Anderson 1976), and Hegel is an idealist. After Hegel's death, the rise of German neo-Kantianism and the rapid development of modern science turned attention away from idealism. Western, or in another formulation Hegelian, Marxism, was devised nearly simultaneously but independently in 1923 by Lukács and Korsch, the former more than the latter, in calling attention to the central Hegelian thrust of Marx's position.

\section{On Human Flourishing}

I have been suggesting that Marx is a critical Hegelian, but that traditional, Russian and Chinese forms of Marxism are all in related ways anti-Hegelian. What difference does it make? Philosophical theories are formulated to respond to perceived difficulties, enigmas or conundra. It would thus be useful to address the main difficulty for which Marx's position was formulated.

I suggest that Marx, who never turns his back on philosophy, instead seeks to respond to a traditional philosophical concern. Though Marx is among other things 
a student of modern industrial society, this is not and should not be seen as his basic concern. His main interest is not the so-called law of human history, nor the anatomy of modern industrial capitalism, nor the interpretation of ancient Greek materialism, nor a theory of alienation, nor the relation of superstructure and base, nor related difficulties, though all are important, but rather to identify and to promote the real conditions of what I will be calling human flourishing.

The term "to flourish" refers to the social development of a fully-individual human being. This term presupposes a distinction between two kinds of needs. Basic or reproductive needs are often described through the canonical phrase of food, clothing and shelter. Human needs, or the need to develop as a human individual in realizing one's person-specific capacities as a fully individual human being, presuppose the capacity to respond to basic needs. Human flourishing, which runs throughout the Western tradition, takes different forms at different times.

The Socratic concern with life in the social context continues in modern industrial society. Yet human flourishing is understood differently in Ancient Greece and in the modern world. In the former, it centres on happiness (eudaimonia) and/or virtue that in a class-based society was mainly reserved for the few. In the modern world, at least since Rousseau, a number of observers think it concerns freedom in all its many dimensions, understood as the full development of individuals.

Now the relevance of philosophical theory to human social practice, precisely the difficulty that led Marx to insist on the need to transcend mere interpretation, is often regarded as suspect. Hobbes, Rousseau, Kant, Hegel, Marx and others are centrally concerned with the general problem of human freedom in the modern social world. Rousseau gives this theme a modern form in famously remarking in the first sentence of the Social Contract that though human beings are born free, everywhere they are in chains.

This striking formulation suggests a basic dualism encompassing an unwritten, tacit, but also unfulfilled contract with human society based on a difference in kind between the obviously mythical state of nature, in which human beings were supposedly free, and the various but unnatural forms of modern society in which one is in practice, and perhaps in theory as well, still not free. Life in the modern world is not directed toward returning to the state of nature. It is rather directed toward constructing a form of modernity that will bring about a more meaningful form of freedom than that supposedly abandoned in leaving the state of nature.

Rousseau's problem echoes in different ways throughout the later debate. Kant is aware of the need to understand freedom in the modern world, but unable to formulate an acceptable approach to it within the confines of critical philosophy. His 
view falters on an obvious contradiction: on the one hand, he describes freedom as rational self-determination; for instance, in acting according to the categorical imperative. On the other, he runs up against the supposed compatibility, in fact an incompatibility, between dualistic conceptions of human action as wholly self-determined and causal determinism in nature. According to Kant, moral action requires formulating a universalizable moral rule and in fact so acting. Yet Kant cannot explain the transition from the a priori to the a posteriori, from self-determination in order to act morally to in fact acting morally in a world that is supposedly causally determined.

Kant is mainly concerned with moral freedom, but Hegel is primarily concerned with social freedom. Hegel's view of freedom is understood in many different ways. Many observers think Hegel is interested in freedom in relating freedom to autonomy. There seems to be broad agreement that the Hegelian view of autonomy culminates in a social view of freedom encompassing both the individual and the group, which different observers often understand as an expansion of the Kantian view of morality into the social realm. Yet there is no consensus about how to understand the Hegelian view of social freedom.

Different observers emphasize one or more aspects of autonomy in pointing to the need to surpass the individual level. The popular stress in the Hegel debate on freedom as autonomy, and autonomy as not moral but ethical, is part of the answer. Yet it fails to identify the specific problem or problems Hegel's theory is meant to address. More specifically, it neglects to examine Rousseau's influential restatement of the question of human flourishing in the form of the modern industrial state, something that for both Kant and the post-Kantian Hegel requires a constructivist approach. At a minimum this means that, unlike Marx, who denies that human beings flourish or even could flourish in modern industrial society, for Hegel they can and do flourish as a group within the institutions they construct for themselves and within which they "recognize" themselves as at home so to speak.

\section{Marx's Hegelianism and Human Flourishing}

Hegel's conception of social freedom is not, like Kant's view of morality, based on rational self-determination, that is, on successfully formulating and following a self-constructed, universalizable rule, a rule valid in all times and places. It is rather based on the idea that the human world is a social construct in which we find or recognize ourselves as who we potentially are, and in the right conditions can 
through development become, in interaction with others and within the institutions of the modern state.

Marx's conception of social freedom builds on Hegel's, with the latter claiming that capitalism and freedom are compatible, and that the institution of the private ownership of the means of production is a basic prerequisite of human freedom. But Marx comprehends this as a main source of the modern inability to achieve human self-development beyond the minimal level of meeting basic or reproductive needs. Marx clearly rejects the Hegelian approach on this point, but he relies on it in another way.

Marx's main suggestion for human flourishing in modern industrial society lies in a Hegelian distinction suggested (but not worked out) in the Elements of the Philosophy of Right between objectification and alienation. Elsewhere I have argued that the constructivist approach runs throughout and links together Kant, Fichte and Hegel, the main German idealists. This view of cognition, which is central to the critical philosophy, is widely known as the Copernican revolution in philosophy, but rarely studied in detail. (see Rockmore 2016)

German idealist thinkers (Kant, Fichte, Hegel, and in my view Marx but not Schelling) are linked together by the effort to formulate a successful version of constructivism. This view comes into classical German philosophy in the often-mentioned but rarely examined Copernican revolution. Hegel's theory of freedom in the modern world, for instance, relies on identifying with and recognizing oneself in the institutions of modern industrial society that one has constructed. Marx, who rejects the view that significant freedom is possible in modern capitalism, contends it will be possible after the abolition of private ownership of the means of production in postmodern communism.

The development of finite human beings as individuals depends on the future separation of objectification and alienation. Marx follows the Hegelian view of objectification, both early and late. In the Paris Manuscripts he identifies alienation as the result of objectification in the capitalist period. In Capital vol. 1 in the chapter on "The Fetishism of the Commodity and Its Secret," he points out that the human quality of labour takes on an objective form in the process of production. Objectification has a dual function as the presupposition of alienation as well as self-development as a human individual. In making, producing or constructing an object, for instance, a commodity destined for sale in the market place, an individual, as Hegel notes in the master-slave analysis, also "objectifies" himself in the form of the object. Objectification is further the way in which a person gives external manifestation to the future individual in developing one's capacities beyond merely meeting one's reproductive needs as a fully individual human being. 


\section{Human Flourishing and Chinese Marxism}

Hegelian Marxism is based on the idea of the revolutionary subject as self-developing in and through its interaction with others and the surrounding natural world. Anti-Hegelian Marxism in all its forms is based, as already noted, on revolutionary self-development through knowledge of the so-called law of human history. I have argued that Marx is a critical Hegelian, and that his Hegelianism is central to his self-assigned task of resolving the problem of human flourishing through the transition from capitalism to communism. I have further argued that Chinese Marxism is a form of classical, non-Hegelian Marxism. In short, non-Hegelian forms of Marxism, including Chinese Marxism, are incompatible with the Marxian project.

Western and Eastern conceptions of human being differ in fundamental ways. Marx and Confucius thus present humanistic views of the world based on different conceptions of finite human being. The Western model stresses a view of the individual that is very different from the Chinese model that, though there are many variations on this theme, overall stresses the group. The modern Western model of the individual emerges over many years. It is already beginning to take shape in the Magna Carta, in which the English people won rights in relation to the king. This basically secular conception later crystallized in the American Constitution in the phrase life, liberty and happiness. It was restated during the French Revolution as liberty, equality and fraternity, and more recently reformulated as the Universal Declaration of Human Rights. Marx, who is a Westerner, understands human beings based on the Western model of a person endowed with inalienable rights, that if necessary justify revolution and develop through the basic transformation, hence the relative discontinuity, of modern Western society.

In contrast, Chinese Marxism insists on a strong continuity with the Chinese tradition, especially Confucianism, which stresses family and social harmony, hence social stability. Though there are many different interpretations of Confucianism, it will suffice here to say that it stresses family, fixed social roles, and social harmony, for instance the practical order, rites, loyalty and filial piety. According to Confucianism, social harmony requires that every individual play a predetermined part in the natural order and play that part well. As Confucius writes, "There is government, when the prince is prince, and the minister is minister; when the father is father, and the son is son." (Confucius 12: 48) 


\section{Two Criticisms}

It will be useful to anticipate two obvious criticisms to the ideas outlined above. I have argued that Marxism is basically anti-Hegelian and Marx is basically Hegelian. I have further suggested that the conceptions of human beings in East and West are basically different. It could be objected that there is no strict distinction between Hegelian and non-Hegelian, or even anti-Hegelian, Marxism, since the development of Marxism is more complex and, instead of a sharp distinction, there is a continuous series of Marxist views that are more or less Hegelian, since none is purely anti-Hegelian and none is purely Hegelian. It could further be objected that the idea of an opposition between a Western conception of human being or man (ren) and an Eastern, basically Confucian conception is an exaggeration, since Confucianism is a collection of different doctrines including, say, Xunxian (and legalist) "state-oriented and Mengxian "aesthetic-ethically" oriented conceptions.

In my view there is merit in both objections. In a sense, it is correct that there is always continuity as well as difference, and the degree of continuity as well as difference is a function of interpretation. This is the case both for the extent to which Marx is Hegelian, and the extent to which Marxism of all kinds is anti-Hegelian. Marx's own Hegelianism is important enough for him to call attention in the Afterword to the second edition of Capital, despite his critical relation to Hegel, to his role as a pupil of the German philosopher. Marx, who was trained as a philosopher according to the standards of the day, and thus thoroughly steeped in Hegel. This has, with very few exceptions, above all Lukács, never been the case for either traditional Russian or Chinese Marxism, where a grasp of Hegel, whose views are not well understood, is undermined by the conviction that Marx supersedes him or at least leaves him behind.

Marx, of course, does not hold any version of this view. He clearly indicates his belief that the correct way to appropriate Hegel's dialectic is to turn it right side up. In this respect, Engels has a thoroughly muddled and finally problematic role. Engels holds a contradictory view of Hegel. On the one hand, we recall that Feuerbach, on whom Engels relies in claiming that Marx turned away from philosophy, hence from Hegel, was a minor Hegelian, later a minor critic of Hegel, and an important Protestant theologian. Yet Engels, who was not trained in philosophy, and who was most familiar with Schelling among the German idealists, thinks that Feuerbach is the only contemporary philosophical genius. He believes, as noted, that Marx simply threw Hegel aside in following Feuerbach away from idealism, away from philosophy, and toward science. This gross exaggeration vastly overestimates Feuerbach's influence on Marx, which was initially important, but 
quickly faded. On the other hand, Engels also says, in contradicting the former view, German socialists are proud to trace their descent from Kant, Fichte and Hegel. (Engels 1989, 24: 459) This point is correct, but Engels, in insisting that Marx left philosophy behind, undermines it.

The other objection is supported by the development of Confucianism that consists of the original view worked out by Confucius as well as related doctrines added to it over the centuries. Now different sources point to differences in emphasis, and though this suggests the need to take differences in emphasis into account, it does mean there is not a central conceptual Confucian core series of beliefs very different from the Western view of human beings, nor suggest that the differences in the different forms of Confucianism are so important as to invalidate the differences not merely in degree, but also in kind, between the Western and Chinese views of humans.

\section{Hegel, Marx and Chinese Marxism}

Marxism takes different forms as part of the continuing effort to realize Marx's project, which is interpreted in different, even incompatible ways. This paper has studied the relation between Hegel, Marx and Chinese Marxism in calling attention to four points. First, it points to the theme of human flourishing as Marx's central problem. Second, it links Marx's proposed solution to realizing individuality in a future post-capitalist phase. Third, it suggests that Marx's understanding of the practical conditions of human flourishing in terms of individuals in a future form of the world depends on his critical Hegelian perspective. Fourth, it identifies basic differences between Western and Eastern, or a specifically Chinese, view, in suggesting that, in virtue of his dependence on Hegel, Marx relies on a specifically Western model of the human individual.

My conclusion follows directly from these four points. The so-called Chinese Dream incorrectly suggests that Chinese Marxism focuses or at least carries further a conception shared by Marx, Chinese Marxism and contemporary China. Marx is, on the contrary, concerned with a Western view of the individual on a critical Hegelian basis. Chinese Marxism, which is not Hegelian, and is not more Hegelian than Russian Marxism or classical Marxism, is mainly concerned with a traditional Confucian conception of the human being. This conception is opposed to the Western model as well to its Marxian variation. I thus conclude that the so-called Chinese Dream is unlikely to reach Marx's goal, since the Western and Eastern conceptions of human being are essentially different. 


\section{References}

Anderson, Kevin B. 1995. Lenin, Hegel, and Western Marxism: A Critical Study. Champaign: University of Illinois Press.

Anderson, Perry. 1976. Considerations on Western Marxism. London: Verso.

Chan, Adrian. 2003. On Chinese Marxism. London and New York: Bloomsbury.

Confucius. Analects XII, 11, translated by James Legge. The Analects (Lun Yu) English translation: James Legge. Accessed April 15, 2018. www.ctext.org. Edited by Cambridge Chinese Classics. www.camcc.org.

Engels, Friedrich. 1989. “Karl Marx's Funeral.” In Marx Engels Collected Works, by Karl Marx and; Friedrich Engels, vol. 24, Marx and Engels 1874-83, 467-71. Chadwell Heath: Lawrence \&Wishart.

- 1989 "Socialism: Utopian and Scientific." In Karl Marx Friderick Engels Collected Works by Karl Marx and; Friedrich Engels, vol. 24, Marx and Engels 1874-83, 281-321. Chadwell Heath: Lawrence \& Wishart.

-.1996. Ludwig Feuerbach and the Outcome of Classical German Philosophy. New York: International Publishers.

Gu, Xin. 1996. "Subjectivity, Modernity, and Chinese Hegelian Marxism: A Study of Li Zehou's Philosophical Ideas from a Comparative Perspective." Philosophy East and West 46 (2), April: 205-45.

Hu, Fuming. 1993. "Practice is the Criterion of Truth." Contemporary Chinese Thought 25 (2): 17-26.

Kolakowski, Leszek. 1978. Main Currents of Marxism, vol. 3. Translated by P. S. Falla. Oxford: Clarendon Press.

Knight, Nick. 2005. Marxist Philosophy in China: From Qu Qiubai to Mao Zedong, 1923-1945. Dordrecht: Springer.

Lin, Tongqi, Henry Rosemont, Jr., and Roger T. Ames. 1995. "Chinese Philosophy: A Philosophical Essay on the 'State of the Art'." The Journal of Asian Studies 54 (3), August: 727-58.

Mandel, Ernest. 1982. "Introduction to Karl Marx." Capital: A Critique of Political Economy. Translated by Ben Fowkes. Harmondsworth: Penguin.

Rockmore, Tom. 2016. German Idealism as Constructivism. Chicago: University of Chicago Press.

Stalin, Joseph. 1941. History of the CPSU (Short Course). New York: International Publishers.

Stedman Jones, Gareth. 2016. Karl Marx: Greatness and Illusion. Cambridge: Harvard University Press.

Xu, Changfu. 2016. Marxism, China and Globalization. Berlin: Paradox Verlag. Wang, Robin. 2014. "Zhang Shiying and Chinese Appreciation of Hegelian Philosophy." Asia Network Exchange 22 (1), fall: 90-96. 
Wang, Ruoshui. 1983. "A Defense of Humanism.” Wenhui Bao = Wenhui Daily, Shanghai, January 17.

Yuhuai He, Henry. 2001. Dictionary of the Politics of the People's Republic of China. London: Taylor and Francis. 